\title{
FAKTOR-FAKTOR KETERLAMBATAN PENGEMBALIAN SENSUS HARIAN RAWAT INAP DI RSUD KAB. CIAMIS
}

\author{
Firman Cahya Diningrat ${ }^{1}$, Ida Sugiarti ${ }^{2}$ \\ 1,2Poltekkes Kemenkes Tasikmalaya \\ firman.diningrat132@gmail.com ${ }^{1}$, sugiarti.ida@gmail.com²
}

\begin{abstract}
The implementation of good medical records will support the implementation of health improvement services in hospital, one of them is making report based on the daily census. The return of daily hospitalizazion census to the medical record unit in RSUD Kab. Ciamis is often delayed. This research aims to know the factors of delay returns daily census of hospitalizazion to medical record unit at RSUD Kab. Ciamis. The method used in this research is qualitative method with phenomenological approach. The data collecting used interview and observation techniques in 8 informants. Data analysis is done by the data reduction, data presentation and withdrawal data conclusion or verification. Based on this research, it is known that the daily census has been delayed for two weeks, it is incompatible with the standard operating procedures (SOP) in which the daily census should have sent to the Medical Records back at least at 09.00 am the next day. The cause of the delay returns daily census is the lack of responsibility of the officer and the mismatch workload which is resulting in low productivity of labour. It is necessary for the holding of related SOP socialization census data collection daily hospitalization for officers, especially for the nurses in the implementation mechanism census daily data.
\end{abstract}

Keyword: Delays, Returns, Census, Hospitalization

\begin{abstract}
Abstrak
Penyelenggaraan rekam medis yang baik akan menunjang terselenggaranya peningkatan pelayanan kesehatan di rumah sakit, salah satunya adalah pembuatan laporan berdasarkan sensus harian. Pengembalian sensus harian rawat inap ke unit rekam medis di RSUD Kab. Ciamis sering mengalami keterlambatan. Penelitian ini bertujuan untuk mengetahui faktor-faktor keterlambatan pengembalian sensus harian rawat inap ke unit rekam medis di RSUD Kab. Ciamis. Metode yang digunakan dalam penelitian ini adalah metode kualitatif dengan pendekatan fenomenologi. Pengumpulan data menggunakan teknik wawancara dan observasi pada delapan informan. Analisis data yang dilakukan adalah dengan cara reduksi data, penyajian data serta penarikan data simpulan atau verfikasi. Berdasarkan hasil penelitian diketahui bahwa sensus harian mengalami keterlambatan selama dua minggu, hal tersebut tidak sesuai dengan standar operasional prosedur (SOP) dimana sensus harian harus dikembalikan ke bagian Rekam Medis paling lambat jam 09.00 WIB hari berikutnya. Penyebab dari keterlambatan pengembalian sensus harian adalah kurangnya tanggung jawab petugas dan ketidaksesuaian beban kerja sehingga mengakibatkan rendahnya produktivitas kerja. Untuk itu perlu diadakannya sosialisasi terkait SOP pengumpulan data sensus harian rawat inap untuk petugas, utamanya untuk perawat dalam mekanisme pelaksanaan sensus data harian.
\end{abstract}

Kata Kunci : Keterlambatan, Pengembalian, Sensus, Rawat Inap 


\section{PENDAHULUAN}

Rumah sakit menurut Peraturan Menteri Kesehatan Republik Indonesia No.340/MenKes/Per/III/2010 tentang Rumah Sakit, yang dimaksud rumah sakit adalah institusi pelayanan kesehatan yang menyelenggarakan pelayanan kesehatan perorangan secara paripurna yang menyediakan pelayanan rawat inap, rawat jalan dan gawat darurat. Untuk meningkatkan mutu pelayanan rumah sakit didukung dengan adanya penyelenggaraan rekam medis yang merupakan salah satu upaya pelayanan kesehatan yang bertujuan untuk menunjang tercapainya tertib administrasi dalam meningkatkan mutu pelayanan kesehatan. Salah satu pelayanan yang diberikan bidang administrasi adalah pelayanan rekam medis.

Menurut Permenkes No. 269/Menkes/Per/III/2008 tentang Rekam Medis, yang dimaksud rekam medis adalah berkas yang berisi catatan dan dokumen antara lain identitas pasien, hasil pemeriksaan, pengobatan yang telah diberikan serta tindakan dan pelayanan lain yang telah diberikan kepada pasien. Selain itu, rekam medis adalah keterangan baik yang tertulis maupun yang terekam tentang identitas, anamnesa, pemeriksaan fisik, laboratorium, diagnosa serta segala pelayanan dan tindakan medis yang diberikan kepada pasien dan pengobatan baik yang di rawat inap, rawat jalan maupun yang mendapatkan pelayanan gawat darurat (Depkes RI, 2006).

Penyelenggaraan rekam medis yang baik akan menunjang terselenggaranya upaya peningkatan pelayanan kesehatan di rumah sakit, salah satunya adalah pembuatan laporan yang dilakukan oleh setiap rumah sakit dengan sumber data pelaporan berasal dari sensus harian rawat jalan, sensus harian rawat inap, register masing-masing unit pelayanan dan berkas rekam medis (Budi, 2011).

Sensus harian rawat inap merupakan kumpulan data pasien yang masuk dan keluar bangsal. Sensus harian rawat inap memuat informasi semua pasien masuk, pindahan, dipindahkan, dan keluar baik dalam keadaan hidup maupun meninggal dunia selama 24 jam mulai dari pukul 00.00 WIB s.d. 24.00 WIB setiap harinya. Informasi yang diperoleh dari sensus harian rawat inap yaitu berupa data yang akan diolah menjadi sebuah informasi yang dibutuhkan oleh rumah sakit (Hatta, 2010).

Peranan kegiatan sensus harian rawat inap dalam rekam medis adalah sebagai data dalam kegiatan reporting dalam pembuatan sensus harian rawat inap mengacu pada standar dan prosedur yang telah ditentukan oleh direktur rumah sakit serta diolah dengan cepat, tepat dan akurat sehingga dapat menghasilkan informasi yang berkualitas. Jika pengolahan data sensus harian pasien rawat inap tidak cepat, tepat dan akurat maka akan menyulitkan tenaga rekam medis dalam proses pembuatan pelaporan rumah sakit sehingga tidak dapat dipertanggung jawabkan.

Penelitian mengenai faktor keterlambatan pengembalian sensus harian rawat inap di rumah sakit banyak diteliti oleh peneliti. Hasil penelitian Ika Septiana Dewi (2012), yang berjudul "Faktor Penyebab Keterlambatan Pengambilan Sensus Harian Pasien Rawat Inap di RSUD Sleman", menunjukkan kurangnya Sumber Daya Manusia (SDM) di bagian sensus harian pasien rawat inap di setiap bangsal, dan dalam pelaksanaannya pengambilan sensus di setiap bangsal perawatan tersebut tidak dilakukan setiap hari.

Penelitian lainnya oleh Margareta Iriyati (2008), tentang "Faktor Faktor Yang Mempengaruhi Keterlambatan Penyusunan Laporan Data RL1 Di Instalasi Radiologi Di RSUP Dr. Sardjito Yogyakarta", terdapat faktor utama yang menyebabkan keterlambatan pengembalian sensus harian rawat inap adalah Sumber Daya Manusia (SDM) yang tidak menjalankan tugasnya sesuai dengan tanggung jawabnya karena petugas itu sendiri kurang mengetahui dalam administrasi khususnya mengenai pelaporan dan komputerisasi dan belum adanya koordinasi yang baik antara atasan dan bawahan.

Berdasarkan studi pendahuluan di RSUD Kabupaten Ciamis penulis menemukan adanya keterlambatan dalam pengembalian sensus harian rawat inap dari bangsal ke unit rekam medis. Hal tersebut tidak sesuai dengan Standar Operasional Prosedur yang berlaku, pengembalian lembaran sensus harian rawat inap harus sudah dikirim ke bagian unit rekam medis paling lambat jam 09.00 WIB pagi hari berikutnya (SOP pengumpulan data Sensus Harian Rawat Inap RSUD Ciamis). Beberapa bangsal mengembalikan lebih dari dua minggu, rata-rata pelaksanaan pengembalian sensus harian rawat inap belum sesuai dengan standar operasional prosedur yang berlaku.

Dampak dari keterlambatan pengembalian sensus harian rawat inap ke unit rekam medis di Rumah 
Sakit Umum Daerah Kabupaten Ciamis yaitu, terlambatnya pembuatan pelaporan dan penyajian data, baik keperluan internal maupun eksternal untuk data kunjungan sepuluh besar penyakit dan indikator rawat inap.

Sehubungan dengan permasalahan dan uraian di atas penulis tertarik melakukan penelitian dengan judul "Faktor-Faktor Yang Mempengaruhi Keterlambatan Pengembalian Sensus Harian Rawat Inap ke Unit Rekam Medis di Rumah Sakit Umum Daerah Kabupaten Ciamis"

\section{METODE}

Jenis penelitian yang digunakan adalah penelitian kualitatif dengan menggunakan pendekatan fenomenologi. Instrumen penelitian menggunakan pedoman wawancara semi terstruktur, buku catatan serta alat perekam sebagai alat bantu melakukan pengumpulan data juga dengan menggunakan lembar observasi. Cara pengumpulan data dengan wawancara menggunakan triangulasi.Analisis data kualitatif yaitu reduksi data, penyajian data serta penarikan data simpulan atau verfikasi.

\section{HASIL}

\section{Standar waktu pengembalian sensus harian rawat inap}

Menurut informan pendukung waktu pengembalian sensus harian rawat inap di dalam standar operasional prosedur (SOP) adalah 1x24 jam, berikut ungkapan informan tentang hal tersebut

"Euuu kalau yang sesuai dengan SOP seharusnya kan $1 \times 24$ jam ya, jadi pengembalian sensus itu pagi hari berikutnya sebelum jam 9" (Informan 6).

"Kalo pengembaliannya harusnya sih tiap hari yah tiap tanggal berikutnyah euu satu hari pelayanan cuma kan disini kadang-kadang ada yang satu hari ada yang di apa namanya ditumpuknya, bisa ditahan dulu kitu ku itu gituh dirapelkan gitu a" (Informan 7).

"Alur pengembaliannya eиuи sensus harian rawat inap dikembalikan ke rekam medis itu 1x24 jam seharusnyah 1x24 jam namun banyak yang terlambat setengah dari bangsal yang terdapat di RSUD ciamis melakukan pengembalian terlambat." (Informan 8).

\section{Pengembalian sensus harian rawat inap tidak tepat waktu.}

Menurut informan pengembalian sensus harian rawat inap dari bangsal ke unit rekam medis adalah dua minggu hal tersebut tidak sesuai dengan ketetapan yang berlaku. Berikut ungkapan informan tentang pengembalian sensus harian rawat inap:

"Kalo waktu pengembalianya dari kami paling dua minggu, harusnya memang tiap hari tapi kan eеuuu pasiennya banyak jadi pengisian sensusnya aga terhambat dikarenakan banyaknya pengklaiman karnakan ini kelas tiga yah, dahlia mah jadi banyaknya pasien asuransi seperti BPJS dan JAMKESMAS”, (Informan 3).

"Kalau dari sayahmah dari ruang mawar suka mengembalikan sensus paling dua mingguan lebih lah, memang seharusnyah sensus itu setiap hari dikirimnya, tapi dari kita mah udah biasa ngirimnya dua minggu sekali" (Informan 5).

Berbeda dengan pendapat informan 1 dan 3 pengembalian sensus yang dilakukan yaitu tiga minggu sekali bahkan satu bulan sekali. Berikut ungkapan informan mengenai pengembalian sensus harian rawat inap.

"saya mah pengembalianya biasanya suka satu bulan sakali soalnya kan buku TPRSS itu jarang diisi dengan lengkap yah seperti jam masuk, jam keluar, tanggal berapa masuk, terus diagnosa atau pasien pindahan nah kebanyakan buku TPRSS itu tidak diisi dengan lengkap jadi yang ngisi sensus itu harus membuka dokumen wah inimah pasien jam berapa masuknya, belum lagi kalau buku status nya itu dibawa ke IPJ, jadi kan otomatis menyita waktu lagi jadi terlambat, maleslah buku nya juga gatau dimana, coba di TPRS itu teh lengkap jadi kan gampang tinggal nyalin, nah itu pengisian data itu yang kurang kesadaran perawatnya, perawat itu kurang menyadari tugasnya itu seperti apa harusnya kan kalau pulang visite harus diisi lengkap, jadi gampang" (Informan 1).

"Kalo pengembalianya sih biasanya saya ngasihnya tiga mingguan ya soalnya kalo di ICU kan pasiennya rata-rata pasien keluarnya lama ya jadi yasudah di rapelkan aja jadi tiga minggu sekali kadang paling cepet ya dua mingguan lah" (Informan 2).

\section{Cara pengisian sensus harian rawat inap.}

Semua informan yang terlibat dalam penelitian ini berpendapat bahwa proses pengisian sensus harian 
rawat inap menurut informan yaitu mengisi nama, alamat, jam masuk, jam keluar, diagnosa pasien pindah dan dipindahkan. Berikut ungkapan informan tentang proses pengisian sensus harian rawat inap.

"Pengolahan sensus paling ngisi jam masuk dan keluar, diagnosa, pasien pindahan dan yang dipindahkan, sama nama pasien, biasa aja gituh" (Informan 1).

"Pengolahan sensus ya gitu aja ngisi jam masuk dan keluar, pasien pindahan, yang dipindahkan, diagnosa sama nama pasien gitu aja paling" (Informan 2).

"Pengolahanya sih ya cuma ngisi nama, alamat, umur jam masuk dan keluar, diagnosa dan cara pembayaran" (Informan 3).

"Pengolahannya seperti ngisi nama, alamat, tanggal masuk tanggal kaluar sama diagnosis terus satu lagimah pasien yang dipindahkan sama pasien pindahan" (Informan 4).

"Mengelolanya mah cuma mengisi jam masuk jam keluar, diagnosa, pasien pindahan, pasien dipindahkan paling cuma gitu aja kalou pengolahan disinimah" (Informan 5).

\section{Pelaksanaan pengembalian sensus harian rawat inap.}

Pelaksanaan pengembalian sensus harian rawat inap menurut informan adalah mengisi lembar sensus dan mengembalikan sensus dari bangsal ke unit rekam medis dengan informasi-informasi yang dibutuhkan seperti nama dan alamat. Berikut ungkapan informan tentang waktu pengembalian sensus harian rawat inap:

"Alur nya ya seperti yang disebut tadi ngisi nama alamat dan yang lainya kalo prosedur pengembaliannya paling dari kita dibalikin lagi ke PPL untuk diolah lagi disana” (Informan 1).

"Eeuиuи untuk alur nya paling cuma ngisi formulir sensus saja, sedangkan untuk prosedurnya dikembalikan lagi ke RM untuk diolah lebih lanjut" (Informan 2).

"Alur nya ya seperti yang di sebut tadi ngisi nama, alamat, pasin pindah dipindahkan dan lainya kalo prosedur pengembaliannya dari bangsal di kirim ke $P P L$ " (Informan 3).

"Kalo alur sama prosedur nyamah eеeuuu paling kita cuma mengisi lembaran sensus aja dan untuk prosedurnya paling dikembalikan lagi ke rekam medisnya" (Informan 4).

"Kalo untuk prosedur nya lembar sensus yang dari bangsal itu dikembalikan lagi ke rekam mediknya yah nah sedangkan alurnya si sensus itu diisi oleh kita mulai dari nama, alamat, diagnosa dan yang lainya, paling cuma gitu aja" (Informan 5).

\section{Beban kerja petugas administrasi atau petugas bangsal.}

Beberapa informan menyebutkan bahwa hal yang membuat pengembaian sensus harian rawat inap adalah banyaknya pekerjaan, hal tersebut juga terjadi karena sensus harian seharusnya diisi oleh perawat ruangan. Berikut uraian informan mengenai hal tersebut :

"Seharusnya yang diberi kewenangan untuk mengisi itu perawat ya a seharusnyamah tapi mungkin karena perawatnya yang terlalu banyak pekerjaan jadi kita yang mengisi sensus nya a" (Informan 3).

Informan dua juga berpendapat bahwa petugas pengisian sensus harian rawat inap memiliki pekerjaan lain selain melakukan pengisian sensus harian rawat inap. Berikut uraian informan mengenai hal tersebut

"Mungkin kerjaan kita nya juga ga cuma mengisi sensus aja yah kita juga harus ngurusin pekerjaan yang lain selain dari sensus seperti ngurusin keuangan jadi sebenarnyamah kendalanya paling cuma gitu aja" (Informan 2).

Berbeda dengan pendapat informan lima bahwa keterlambatan pengembalian sensus harian rawat inap juga disebabkan karena kebiasaan petugas pengisian dalam pengembalian sensus harian rawat inap yang tidak tepat waktu. Berikut uraian informan mengenai hal tersebut.

"Apayah kendalanya kayanya emang mungkin karena kitanya terlalu sibuk dengan kerjaan lain jadi ga sempet ngisi sensus tepat waktu da dari kami juga udah biasa ngembaliinnya dua minggu sekali" (Informan 5).

\section{Tanggung jawab petugas pengisian sensus harian} rawat inap.

Informan enam menyebutkan bahwa keterlambatan pengembalian sensus harian rawat inap juga 
disebabkan karena kurangnya tanggung jawab petugas pengisian sensus harian rawat inap. Berikut uraian informan mengenai hal tersebut

"Kendalanya mungkin yaa euuu, apayah euuи mungkin kurang tanggung jawab dari petugas di bangsalnya mungkin ya kalo ada yang suka terlambat gitu, kan jadi mengahmbat juga ke pembuatan laporan rumah sakitnya" (Informan 6).

Hal tersebut juga didukung oleh informan delapan yang menyebutkan bahwa perawat yang seharusnya melakukan pengisian sensus harian rawat inap kurang bertanggung jawab. Berikut uraian informan mengenai hal tersebut

"Kendalanyah yaaa salah satunya tidak ada tanggung jawab dari pada euuuu petugas yang melakukan dinas malam atau perawat yang melakukan dinas malam karena mereka mungkin masih belum adanyah rasaa rasa apaya rasa tanggung jawab lebih untuk melakukan itu karena yang didalam mainset mereka perawat hanyalah merawat pasien tidak melakukan administrasi itu menjadikan sensus harian diambil alih tugas admin ruangan yang dilakukan pada pagi hari dilakukan еииии ара euuи sensus itu dikerjakannya pada pagi hari oleh petugas admin ruangan" (Informan 8).

\section{Dampak dari keterlambatan pengisian sensus harian rawat inap.}

Dampak dari keterlambatan pengembalian sensus harian yaitu memperlambat pembuatan statistik pelaporan rumah sakit yang juga dapat menghambat proses pencairan keuangan. Berikut ungkapan informan mengenai dampak dari keterambatan pengembaian sensus harian rawat inap.

"Dampak dari keterlabatan itu sendiri yaitu memang memperlambat dalam proses pembuatan pelaporan statistik rumah sait yang nantinya akan menghambat pula dalam proses pencairan keuangan karena bisa dilihat dari kunjungan atau dari statistik rumah sakit" (Informan 6).

"Dampak keterlambatan sensus itu sendiri ya memang memperlambat satu euu statistik rumah sakit yang kemudian akan memperlambat pula terhadap pencairan keuangan karena euuu dilihat dari kunjungan atau dari statistik rumah sakit tersebut" (Informan 8).

Sedangkan menurut informan tujuh yang merupakan petugas rekam medis (informan pendukung) menyebutkan bahwa dampak dari keterlambatan pengembalian sensus yaitu terlambatnya penghitungan statistik non indikator rumah sakit. Berikut ungkapan informan tentang dampak keterlambatan pengembalian sensus harian.

"Dampak keterlambatanya teh mungkin euu kalo penghitungan statistik non indikator rumah sakit juga lambat akhirnya gituh kan euu lambat jadi ga bisa keterlambatan itu jadi ga bisa euuu ngeliat kondisinya situasi ruangan tiap hari gitu a jadi ga bisa liat BOR tiap hari ga bisa lihat BOR tiap per minggu ga bisa lihat per bulan, perbulanamah mungkin telat juga perbulannya a cuma itu mungkin dari sayahmah" (Informan 7).

\section{PEMBAHASAN}

\section{Waktu pengembalian sensus harian rawat inap ke unit rekam medis}

Pengumpulan data sensus harian inap merupakan kegiatan pengumpulan sensus harian rawat inap dari setiap ruang perawatan yang akan digunakan sebagai dasar perhitungan statistik rumah sakit dengan ketentuan sebagai berikut :

Lembaran sensus harian harus sudah dikirim ke bagian Rekam Medis paling lambat jam 09.00 WIB hari berikutnya. Sebelum jam 09.00 WIB, petugas bagian Rekam Medis menerima dan menanda tangani buku ekspedisi pengiriman sensus harian yang dikirim dari setiap bagian perawatan.

Menurut pendapat Huffman (1994), sensus harian adalah jumlah pasien dalam atau residen yang ada pada waktu pengambilan sensus setiap hari, tambah pasien dalam atau residen yang masuk dan pulang setelah saat pengambilan sensus hari sebelumnya. Sedangkan menurut Direktorat Jendral Pelayanan Medik (2005), sensus merupakan kegiatan pencacahan atau penghitungan pasien rawat inap yang dilakukan setiap hari pada suatu ruang rawat inap, berisi mutasi keluar masuk pasien selama 24 jam mulai dari 00.00 WIB sampai dengan 24.00 WIB.

Waktu pelaksanaan pengembalian sensus harian rawat inap di Rumah Sakit Umum Daerah Kabupaten Ciamis menurut pendapat informan yang bertugas di beberapa bangsal di Rumah Sakit Umum Daerah Kabupaten Ciamis sensus harian rawat inap dikembalikan dari bangsal ke unit rekam medis 
yaitu setiap dua minggu sekali, bahkan bisa sampai satu bulan sekali padahal informan itu sendiri menyadari bahwa seharusnya sensus harian rawat inap dikembalikan setiap hari ke unit rekam medis. Selaras dengan pendapat informan pendukung bahwa waktu pengembalian sensus harian rawat inap harus sesuai dengan standar operasional prosedur (SOP) yang berlaku. Di dalam standar operasional prosedur (SOP) tertera bahwa waktu pengembalian sensus harian rawat inap harus sudah dikirim ke bagian rekam medis paling lambat jam 09.00 WIB hari berikutnya, jadi seharusnya pengembalian sensus harian rawat inap dilakukan setiap hari. Tujuan diadakan pelaksanaan sensus harian rawat inap adalah untuk memperoleh informasi semua pasien yang masuk dan keluar rumah sakit selama 24 jam.

\section{Pelaksanaan pengelolaan sumber daya manusia tentang alur prosedur pengembalian sensus harian rawat inap dari bangsal ke unit rekam medis.}

Prosedur pengumpulan data sensus harian rawat inap di Rumah Sakit Umum Daerah Kabupaten Ciamis berdasarkan standar operasional prosedur (SOP) yang berlaku, sebelum jam 09.00 WIB, petugas bagian rekam medis menerima dan menanda tangani buku ekspedisi pengiriman sensus harian yang dikirim dari setiap bagian perawatan selanjutnya petugas bagian rekam medis mengkoreksi data tersebut dan mencocokannya dengan buku register dan daftar pasien pulang setelah yakin akan kebenaran data tersebut, petugas bagian rekam medis membuat tabulasi data yang akan digunakan sebagai dasar dalam perhitungan statistik rumah sakit.

Waluyo (2001) menerangkan bahwa alur merupakan jalinan cerita atau kerangka dari awal sampai akhir yang merupakan jalinan konflik antara dua tokoh yang berlawanan. Sedangkan menurut Mulyadi (2001), prosedur merupakan suatu urutan kegiatan, biasanya melibatkan beberapa orang dalam suatu departemen atau lebih yang di buat untuk menjamin penanganan secara seragam transaksi perusahaan yang terjadi berulang-ulang.

Berdasarkan hasil wawancara dan observasi langsung di Rumah Sakit Umum Daerah Kabupaten Ciamis, terhadap informan diperoleh bahawa alur prosedur pengisian sensus harian rawat inap dimulai dari pengisian alamat, umur jam masuk dan keluar, diagnosa dan cara pembayaran, pasien pindahan dan yang dipindahkan, nama pasien, selanjutnya sensus harian rawat inap diserahkan ke bagian unit rekam medis. Pengisian sensus harian rawat inap di Rumah Sakit Umum Daerah Ciamis diisi atau dilengkapi oleh petugas administrasi ruangan, yang seharusnya pengisian sensus harian rawat inap diisi oleh perawat ruangan.

Menurut informan pendukung alur prosedur pengembalian sensus harian rawat inap dari bangsal ke unit rekam medis adalah petugas atau perawat dari bangsal menyerahkan secara langsung sensus ke unit rekam medis setiap hari atau 1x24 jam. Terdapat pengembalian sensus yang terlambat bangsal meliputi lima dari sebelas bangsal yang ada di Rumah Sakit Umum Daerah Kabupaten Ciamis.

Hal tersebut selaras dengan penelitian Yana (2014), mengenai sensus harian pasien rawat inap berisi data yang harus dikumpulkan setiap hari selama 24 jam periode waktu pelaporan. Pihak yang memegang peran penting dalam pengisian sensus harian pasien rawat inap adalah perawat.

Alur prosedur pengumpulan data sensus harian rawat inap tidak sesuai dengan SOP yang berlaku, dimana pengisian sensus diisi oleh petugas administrasi ruangan, pengembalian sensus tidak sesuai dengan prosedur. Hal tersebut dikarenakan tidak semua petugas tahu tentang SOP pengumpulan data sensus harian dikarenakan kurangnya sosialisasi tentang SOP pengumpulan data sensus harian rawat inap dan beban kerja tidak sesuai dengan banyaknya petugas.

\section{Kendala yang mengakibatkan keterlambatan pengembalian sensus harian rawat inap.}

Berdasarkan hasil penelitian yang dilakukan di Rumah Sakit Umum Daerah Kabupaten Ciamis menurut informan pendukung mengungkapkan bahwa kendala yang mengakibatkan keterlambatan pengembalian sensus harian rawat inap adalah kurangnya tanggung jawab dari petugas dalam pengisian sensus harian rawat inap. Sedangkan menurut pendapat petugas administrasi bangsal di ruangan yang bertugas mengisi sensus harian rawat inap, kendalanya yaitu adanya pekerjaan lain yang bukan hanya mengisi formulir sensus harian rawat inap saja. Petugas administrasi ruangan juga mengerjakan pekerjaan lain diantaranya mengurus keuangan, pengklaiman dan kuantitas pasien yang banyak menyebabkan petugas terhambat dalam melakukan pengisian formulir sensus harian rawat inap. Pengisian sensus harian rawat inap yang 
seharusnya diisi oleh perawat pada malam hari mulai jam 00.00 WIB sampai dengan jam 24.00 WIB setiap harinya namun pekerjaan pengisian sensus harian rawat inap diisi oleh petugas administrasi bangsal ruangan pada pagi harinya.

Kendala dari keterlambataan sensus harian rawat inap akan berpengaruh terhadap terlambatnya penghitungan statistik non indikator rumah sakit, dan juga dapat menghambat proses pencairan keuangan, hal tesebut pernah terjadi di RSUD Kab. Ciamis dikarenakan keterlambatan pengembalian sensus harian sering terlambat.

Hal tersebut selaras dengan penelitian Dewi (2012), tentang penyebab keterlambatan pengambilan sensus harian pasien rawat inap yaitu, kurangnya sumber daya manusia (SDM) di bagian sensus harian pasien rawat inap di setiap bangsal, dan dalam pelaksanaannya pengambilan sensus di setiap bangsal perawatan tersebut tidak dilakukan setiap hari.

Penelitian lainnya oleh Iriyati (2008), terdapat faktor utama yang menyebabkan keterlambatan pengembalian sensus harian rawat inap adalah sumber daya manusia (SDM) yang tidak menjalankan tugasnya sesuai dengan tanggung jawabnya karena petugas itu sendiri kurang mengetahui dalam administrasi khususnya mengenai pelaporan dan komputerisasi dan belum adanya koordinasi yang baik antara atasan dan bawahan. Sedangkan dalam penelitian Sukmaningrum (2009), menyebutkan bahwa sosialisasi dan koordinasi yang dilakukan oleh perawat dan petugas sensus di unit rekam medis masih kurang, sehingga pengembalian sensus harian rawat inap ke unit rekam medis terlambat dan menyebabkan data sensus harian pasien rawat inap belum akurat.

\section{SIMPULAN}

Waktu pengembalian sensus harian rawat inap ke unit rekam medis di RSUD Kab. Ciamis belum sesuai dengan SOP, dimana pengembalian data sensus harian rawat inap dari bangsal dua minggu bahkan bisa sampai satu bulan sekali, sedangkan waktu pengembalian sensus harian rawat inap yang tertera dalam standar operasional prosedur (SOP) yaitu lembaran sensus harian harus sudah dikirim ke bagian Rekam Medis paling lambat jam 09.00 WIB hari berikutnya.
Pelaksanaan pengelolaan sumber daya manusia tentang alur prosedur pengisian dan pengembalian sensus harian rawat inap di RSUD Kabupaten Ciamis, ditemukan belum adanya aturan yang jelas mengenai tugas pokok dan fungsi tentang petugas yang diberi kewenangan dalam pengisian sensus harian rawat inap.

Kendala yang menyebabkan keterlambatan pengembalian sensus harian rawat inap yaitu kurangnya tanggung jawab petugas dalam melakukan pengisian sensus harian rawat inap, dan beban kerja tidak sesuai dengan banyaknya petugas, hal tersebut mengakibatkan produktivitas kerja rendah dan akan mempengaruhi mutu pelayanan Rumah Sakit.

Sejalan dengan simpulan diatas, peneliti dapat merumuskan saran sebagai berikut:

1. Pihak Rumah Sakit perlu memberikan tindakan yang tegas atau tertulis agar standar atau ketentuan yang ditetapkan dengan kenyataan di lapangan dapat selaras.

2. Dilakukannya penghitungan analisis beban kerja terhadap petugas.

3. Perlu diadakannya sosialisasi terkait SOP pengumpulan data sensus harian rawat inap untuk petugas rawat inap utamanya perawat dalam mekanisme pelaksanaannya.

4. Membuat standar operasional prosedur mengenai alur dan prosedur pelaksanaan pengisian sensus harian rawat inap

5. Sebaiknya perlu dilakukannya penelitian lebih lanjut mengenai dampak keterlambatan pengisian sensus harian rawat inap (SHRI).

\section{DAFTAR PUSTAKA}

Aman. 2010. Sumber Daya Manusia [diakses pada tanggal 15 Juni 2015]

Arikunto, S. 2008. Prosedur Penelitian Suatu Pendekatan Praktik. Jakarta: Rineka Cipta.

Budi, S.C. 2011. Manajemen Unit Kerja Rkam Medis. Yogyakarta: Quantum Sinergis Media.

Departemen Kesehatan Republik Indonesia. 2006. Pedoman Penyelenggaraan dan Prosedur Rekam Medis Rumah Sakit (Revisi II). Jakarta: Direktorat Jenderal Bina Pelayanan Medik.

Dewi, I. S. 2012. Faktor Penyebab Keterlambatan Pengembalian Sensus Harian Pasien Rawat 
Inap Di RSUD Sleman. Seleman: Karya Tulis Ilmiah. Tidak di terbitkan [diakses pada tanggal 2 Maret 2015]

Dharmawan, Y. 2006. Sistem Informasi Efisiensi Penggunaan Tempat Tidur Unit Rawat Inap Dengan Menggunakan Indikator Grafik Barber Johnson Di Rumah Sakit Panti Wilasa Citarum Semarang. Semarang: Karya Tulis Ilmiah. Tidak di terbitkan [diakses pada tanggal 5 Maret 2015]

Departemen Kesehatan RI. 2005. Pengisian, Pengolahan dan Penyajian Data Rumag Sakit.Jakarta : UI-Press.

Hatta, G. 2010. Pedoman Manajemen Informasi Kesehatan di Sarana Pelayanan Kesehatan. Jakarta: UI-Press.

Huffman, E. K. 1994. Health Information Management. Berwyn Illinois: Physicians Record Companya.

Iriyati, M. 2008. Faktor Faktor yang Mempengaruhi Keterlambatan Penyusunan Laporan Data RL1 Di Instalasi Radiologi Di RSUP Dr. Sardjito Yogyakarta. Yogykarta: Karya Tulis Ilmiah. Tidak di terbitkan [diakses pada tanggal 2 Maret 2015]

Menteri Kesehatan Republik Indonesia. 2010. Peraturan Menteri Kesehatan Nomor: 340/ Menkes/PER/III/2010 tentang Klasifikasi Rumah Sakit, Jakarta: Departemen Kesehatan Republik Indonesia.

Menteri Kesehatan Republik Indonesia. 2008. Peraturan Menteri Kesehatan Nomor: 269/ Menkes/PER/III/2008 tentang Rekam Medis, Jakarta: Departemen Kesehatan Republik Indonesia.
Mulyadi. 2001. Sistem Akutansi dan Sistem Prosedur [diakses pada tanggal 3 juni 2015].

Noor, J. 2012. Metedologi Penelitian. Jakarta : Kencana.

Notoatmodjo, S. 2010. Metodologi Penelitian Kesehatan. Jakarta : PT RINEKA CIPTA.

Sudra, R. I. 2010. Statistik Rumah Sakit. Yogyakarta: Garaha Ilmu

Sherly, Y. 2014. Pengaruh Pengetahuan Perawat Terhadap Ketepatan Pengisian Sensus Harian Pasien Rawat Inap di RSUD Batara Guru Belopa. Karya Tulis Ilmiah tidak di terbitkan [diakses pada tanggal 10 Juni 2015]

Shofari, B. 2002. Pengelolaan Sistem Rekam Medik 01. Semarang: Perhimpunan Perekam Medik dan Informasi Kesehatan Indonesia.

Sugiyono. 2009. Metode Penelitian Keuantitatif Kualitatif dan $R \& D$. Bandung. CV Alfabeta.

Sukmaningrum, I. 2009. Tinjauan Pelaksanaan Sensus Harian Pasien Rawat Inap Di Rumah Sakit Umum Daerah Kota Yogyakarta. Karya Tulis Ilmiah. Tidak di terbitkan [diakses pada tanggal 2 Maret 2015]

UU No. 44 Tahun 2009 tentang Rumah Sakit. [Online]. Tersedia di: Ifi.or.id/upload/file/ UU_44_tahun_2009_tentang_RS.pdf. [7 Maret 2015]

UU No 29 Pasal 46 ayat 1 Tahun 2004 tentang Praktek Kedokteran.

Waluyo. 2001. Unsus-unsur Dalam Drama. [Oline]. Tersedia di: etd.repository.ugm.ac.id/index.ph $p ?=$ view\& $t y p=h t m l \& i d=69538 \&$ ty $p=$ poton gan\&potongan $=$ S1-2014-2997990 chapter1. $p d f$. [diakses pada tanggal 3 Juni 2015] 